Arawn by Dr. Huggins in I 866 (Phil. Trans., vol. clvi. p. 393); it has been amply confirmed since, and cannot be too forcibly insisted upon. We are unable to place either an upper or a lower limit to stellar dimensions or intrinsic emissive intensity. Until Arcturus was proved to be immeasurably remote, few would have been disposed to credit the existence of a sun in space at least six thousand times as efflulgent as ours is; but we know no reason why Arcturus itself should not be as vastly exceeded by some giant orb at the outskirts of the Milky Way; while we are equally debarred from asserting that among sixth, seventh, twelfth magnitude stars, there may not be found some minute bodies at half the distance from us of $a$ Centauri.

But when we pass from particular to general reasoning, the aspect of the matter changes. No cause has yet been shown why the stars should be exempt from obedience to the "law of large numbers" which provides (as Prof. Edgeworth has ably shown) a clue to other labyrinths of facts. Statistics, it is true, are often misleading, but only when they are wrongly employed. The frequent misuse of a method does not justify its total rejection. And the statistical method is peculiarly liable to misuse. Attempts to get from it more than it will properly give inevitably fail ; and what it will properly give are general statements which should only be generally applied. An average result may not be the less instructive because it is by its nature incapable of furnishing specific data.

The stars then must, on the whole, decrease in brightness as their distances increase, and they must do so according to an underlying fixed law which will be more and more closely conformed to the larger the number of instances included in the generalization. Each descent of one stellar magnitude represents a falling off in light in the proportion of $2 \frac{1}{2}$ to $I$; it represents, accordingly, an augmentation of distance in the proportion of the square root of $2 \frac{1}{2}$, or $I^{\circ} 59$ to $\mathrm{I}$. 'Theoretically, that is to say, stars of any given magnitude are 1.59 times more remote than those one magnitude surerior, $2 \frac{1}{2}$ times ( $159 \times I^{\cdot} 59$ ), where the gap is of two magnitudes, and so on. This would be strictly and specifically true if all the stars were equal; but since they are enormously unequal, the rule may be grossly misleading in particular instances, and can only, by taking wide averages, be brought to approximate closely to actual fact.

The determination of individual parallaxes has always, with astronomical thinkers, been subordinate to the higher aim of obtaining a unit of measurement for sidereal space. Hence continual attempts to fix the "average parallaxes " of classes of stars, which, however, remained futile so long as precarious assumptions supplied the place of direct information. Nor could this be obtained until the exigencies of the research had evoked improved means of practically meeting them. The earlier observers chose the subjects of their experiments entirely with a view to their successful issue. Stars likely, owing to their brilliancy, their swift motion, or both combined, to be nearer the earth than most others, were picked out for measurement, with results, each by itseif of high interest, but worthless for generalizing purposes. It is only a few years since increased skill in the handling of methods authorized an extension of the range of their application. The first systematic plan for investigating " mean parallax" was proposed by Dr. Gill in 1883, and is now in course of combined execution at Yale College and the Cape. The completion last year of a section of the work enabled Dr. Elkin to deduce an average distance of thirty-eight light-years for the ten first magnitude stars of the northern hemisphere; but it would of course be folly to regard this avowedly "provisional and partial" result as a satisfactory basis for definitive conclusions about the distances of more remote classes of stars. At the most, it makes a useful temporary starting-point for some trial-trips of thought through syace. Before long, however, through the exertions of Dr. Gill and Prof. Pritchard, direct measures, not only of all the first, but of most of the second magnitude stars all over the sky, will have been executed; and the proportion between distance and brightness thus established may with some confidence be used as a fathom-line for sounding otherwise inaccessible sidereal abysses.

A. M. CLERKE.

\section{DR. H. BURMEISTER ON THE FOSSIL HORSES AND OTHER MAMMALS OF ARGENTINA.'}

THIS handsome volume is a continuation of the author's monograph on the fossil horses of the Pampean beds of Argentina, of which the first part was published at Buenos Ayres in 1875, and is stated to have been specially brought out for the Paris Exhibition. The author has, however, not done himseif justice as regards the title of this portion of the work, since, in addition to the description of remains of the horses of the Pampean, he also describes and illustrates the osteology of $M e g a$ therium, Mastodon, and Macrauchenia, so that a better title for this volume would have been "The Fossil Horses and other Mammals of the Pampean Deposits."

Like the former part, the text of this volume is printed in parallel columns of Spanish and German; and the execution of the plates leaves nothing to be desired, so far as a clear delineation of the essential features of the specimens portrayed is concerned. All the specimens forming the subject of this monograph, are, as we learn from the introduction, preserved in the National Museum at Buenos Ayres, of which the learned author is the Director ; and, so far as we may judge from the description and figures, that collection of fossil mammals must be unrivalled in the excellence and completeness of its specimens.

The first section of the work, or that to which the title alone properly applies, is devoted to the horses; and the author commences his description by observing that the Equida differ from all other Ungulates in that the premolars are larger than the true molars. For the more generalized species of the Pampean deposits, like Equus principalis of Lund, Dr. Burmeister adopts the Owenian genus Hippidium (Hippidion), remarking that these forms are distinguished from the modern horses by the shorter and more curved crowns of their cheek-teeth, which are of a more simple general structure, and also by a difference in the form of the narial aperture, as well as by their shorter limbs and stouter limb-bones. In the

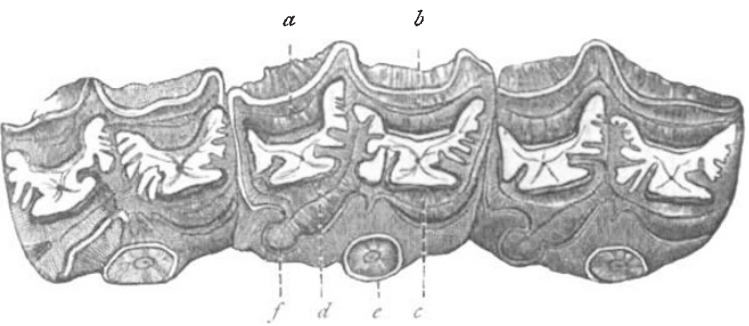

FIG. I. - Three right upper cheek-teeth of Hipparion, $a$, posterior, and $b$, anterior outer crescent ; $c$. anterior, and $d$, posterior inner crescent ; $e$, anterior, and $f$, posterior pillar.

structure of their upper chee's-teeth the horses of this peculiar South American group make, indeed, a decided approach to the more generalized representatives of the family, such as Hipparion. In the litter the anterior pillar of these teeth (Fig. I, $e$ ) forms, as is well known, a I " Los Caballos Fósiles de la Pampa Argent.na," Suplemento. (" Die
fossilen Pferde der Pampasformation," Nachtrags Bericht.) By Dr. Hermann Burmei-ter. Folio, pp. 65, pls. 4. (Buen ss Ayres, 1889.) 
subcylindrical column totally unconnected with the anterior crescent $(c)$; in Hippidium this pillar retains almost the same form as in Hipparion, but becomes connected with the crescent; while in the existing borses the same pillar has become greatly elongated in an antero-posterior direction. Further, in Hippidium the first premolar, which in modern horses is generally absent, and if present is minute and deciduous, is of very large size, and always persists.

The Pliocene Equus stenonis of Europe forms, however, a connecting link in respect of dental characters between the American Hippidium and the modern horses ; and it is therefore to a great extent a matter of individual opinion whether or no the retention of Hippidium as a distinct genus is convenient. A new species referred to Hippidium is described from Tarija, in Bolivia. Of more typical horses the author describes additional remains of Equus curvidens, $E$. argentinus, and $E$. andium; and he adds to his description a useful word of warning in regard to the many forms of fossil horses from other parts of South America which have been described as distinct species, suggesting that all or several of these may be based merely on individual variations.

In the second section of the volume we have a description of remains of other mammals from the Pampean deposits recently acquired by the Museum at Buenos Ayres. The first of these additions is an entire skull of Megatherium americanum, which shows that our previous knowledge was incomplete. This skull formed part of a nearly entire skeleton of a very large individual found in August I 888 on the Rio Salado, but which is as yet but partially disinterred. It shows that instead of the aperture of the nares being bounded superiorly merely by short nasal bones which did not reach within a long distance of the premaxillæ, there was a large prenasal bone extending nearly as far as this point ; while there was also a lateral process projecting forward from the upper part of the maxilla into the nasal aperture. This prenasal bone is $4 \frac{1}{2}$ inches in length, and it is considered probable that it became united with the nasals in the adult. Still more remarkable, however, is the presence of another ossification extending upwards and backwards from the superior surface of the extremity of the premaxillæ towards the prenasal bone, from which it is only separated by a short interval. These two ossifications, we may observe, are evidently a rudiment of the complete bony arch connecting the premaxillæ with the nasals in Mylodon darwini, which was on that account generically separated by Reinhardt as Grypotherium; and they serve to support

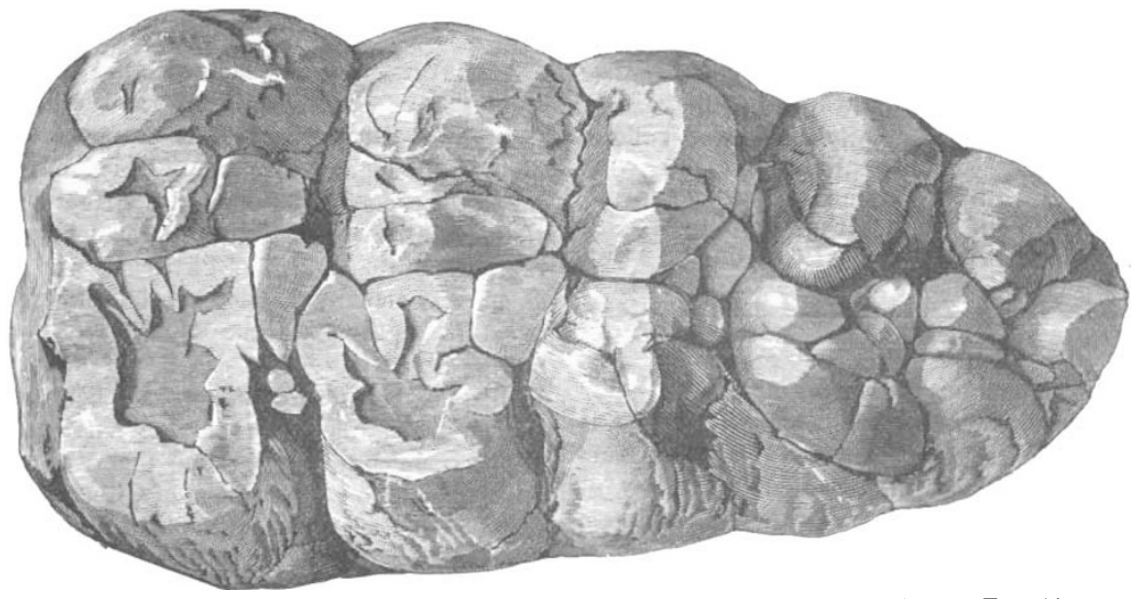

Fig. 2.-The third left upper tru.e molar of Mastodon humboldti; from the Panpean of Buenos Ayres. Two-thirds natural size.

Prof. Flower's view that the last-named species is not separable from the genus in which it was originally placed.

The author next proceeds to the consideration of the skull of that species of Mastodon which he terms $M$. antium. No mention is made of the earlier name $M$. cordillerum, which appears to be the proper one for this species; and in amending the usual spelling $M$. andium to $M$. antium, one cannot help wondering why the same course was not adopted in the case of Equus andium. The object of this part of the work is to show that the reference by the late Dr. Falconer to $M$. cordil lerum (as we will call it) of mandibles from Texas, furnished with long tusks is incorrect, and that this species really had, like its near ally $M$. humboldti, a mandibular symphysis of the same general type as that of the elephants, without any tusks at all in the adult. Figures are given of an immature and of an adult skull with the mandible in situ to support this redetermination. Dr. Burmeister then proceeds to institute a comparison between $M$. cordillerum and $M$. humboldti, in which he states that, although very similar, a careful examination shows very clearly the distinctness of the two forms. Here we may observe that it is to be regretted that no comment or reference is made to the notices and figures published by Falconer and other English writers in refer- ence to these forms; but perbaps the real explanation of this omission is that the libraries at Buenos Ayres are not so well stocked as those of London. According to our author, $M$. cordillerum is the smaller of the two species; the length of the mandible from the condyle to the symphysis being 75 centimetres against 85 centimetres in $M$. humboldti; the last dimension agreeing with the British Museum skull of that species originally described by Falconer in $M$. andium. Falconer's observations as to the more complicated structure of the molars of $M$. humbolti are in the main confirmed. A small specimen of a last upper molar referred to this species in the British Museum is (with the permission of Dr. Woodward) figured in the accompanying woodcut, to show the complexity of the crown, in which the valleys are much blocked by accessory tubercles. In the early stage of wear of this specimen imperfect trefoils of dentine are shown only on the inner columns; but when more worn trefoils would evidently also appear on the outer columns. In the well-worn upper molar of $M$. cordillerum, represented in Plate x., Fig. 5, of the work before us, the absence of a distinct trefoil on the outer columns, which Falconer mentioned as one of the distinctive features of this species, is well shown. Dr. Burmeister further observes that the molars of $M$. cordillerum are characterized by their blackish enamel, and the brown or 
reddish colour of the dentine; while in $M$. humboldti the whole of the crown is of a yellowish or white hue, with darker roots. These distinctive colours are very noticeable in many of the specimens in the British Museum, which have been respectively referred to the two species in question.

The work concludes with descriptions of the remains of two species of the remarkable Perissodactylate genus Macrauchenia, viz. the typical $M$. patachonica of Owen, and $M$. paranensis, originally described by Bravard as Palcotherium. Of the former species an entire skeleton is figured, and the author concludes that the genus is, on the whole, most nearly allied to Palceotherium, although the skull presents some remarkable resemblances to that of the tapirs. It appears, moreover, from the presence of muscular impressions on the cranial bones, that the nose formed a short proboscis, as in the latter group. The author also gives us an elaborate description of the teeth, which are undoubiedly of a Palæotherioid type. It is further observed that in the author's opinion there appear to be no grounds for generically separating $M$. paranensis and the smaller $M$. minuta from the typical genus; and the author concludes his volume with some remarks on the proposal of Dr. F. Ameghino to regard the former as the type of the genus Scalibrinitherium, and to adopt the name of Oxydon[to]therium for the latter.

The above appears to be the gist of Dr. Burmeister's new contributions to our knowledge of the wonderful Tertiary fauna of South America, which he has done so much to enrich. And we congratulate him on the results of this his latest work, and especially on the excellent illustrations by which it is accompanied, since the want of such aids to a right comprehension of the text forms such a great drawback to the work hitherto published by other contemporary South American writers on the same subject.

R. L.

\section{NOTES.}

In his speech at Nottingham on Tuesday evening I-ord Salisbury made a most important reference to the subject of what is called free education. He said :- "There is another question which we have heard a good deal discussed, and that is with regard to what has been, in my opinion, improperly termed free education. I should rather call it assisted education, because I do not know that anybody, however extreme his views, would desire that all the inhabitants of this country, whether rich or poor, whether capable of paying for the education of their children or not, should enjoy free education for those children at the cost of the Chancellor of the Exchequer. On the other hand, I have before expressed the opinion-I expressed it four years ago, before the two last general elections, at Newport-that by making education compulsory, by forcing the people to send their childien to school whether they ask it or not, you were incurring a certain obligation to relieve the burden of that compulsion, where the circumstances of the parent were such that it was too heavy for him to bear. We believe that considerable progress in that direction may be made. We have already introduced measures to that effect in Scotland. I believe that with perfect consistency with sound principle, and merely recognizing the fact that where you enforce a duty upon a man you are bound to make it as easy for him as you can-I believe that it will be possible considerably to extend that principle in England, and very greatly to relieve the difficulties of the working man in that respect. But allow me to say that $I$ consider the question as to its rapidity, and as to its progress, to be a question for the Chancellor of the Exchequer. If he has got the money I have no doubt he will do it, but if he has not got the money he will not. But it is an object to which I believe a great deal of the money of a Chancellor of the Exchequer may very fairly be applied." The Government is to be congratulated on the pledge thus given to consider the matter.
THE Royal Society will hold its anniversary meeting on Saturday. After the meeting the Fellows will dine together.

ON Tuesday the degree of D.C.L., honoris causâ, was conferred in Convocation, at Oxford, upon Mr. Alfred Russel Wallace. Prof. Holland presented him for the degree, and dwelt upon his labour; as a naturalist in Brazil, the Malay Archipelago, and elsewhere; upon the now famous doctrines elucidated by him, and upon the relations between him and Mr. Darwin, reflecting equal honour upon both.

A Conference, called by the National Association for the Promotion of Technical Education, was held in the Manchester Town Hall on Tuesday. About 300 delegates were present from the different technical schools and associations throughout the Kingdom. The chair was occupied at first hy the Mayor of Manchester, and subsequently by Mr. Rathbone, M.P. General Donnelly was present to represent the Science and Art Department, South Kensington. Sir Henry Roscoe, M.P., sir Edmund Currie, Mr. A. H. D. Acland, M.P., and Mr. Mather, M.P., were among those present. The discus ions related to the question of the working of the Technical Instruction Act, I88g. A report was read by Sir Henry Roscoe, showing that the Act was being adopted partly or wholly in a large number of towns throughout the Kingdom. The meeting will do great good, and we shall refer to it next week.

ACCORDING to a circular which has recently been sent to the leading physicists, electricians, and others interested in the history of English science, it is proposed to establish a Gilbert Club, the inaugural meeting of which has been convened this day in the rooms of the Society of Arts at 4.30 p.m. The object of the Club is to do justice to the memory of the illustrious President of the College of Physicians who was in the possession of, and was actually carrying on, the true experimental method of scientific inquiry at a time when Bacon was only talking and writing about it. There can be no doubt that the claims of William Gilbert, of Colchester, have been to a great extent overshadowed by the fame of the renowned Lord Chancellor, and it is much to be regretted that we have not had handed down to us more of the results of Gilbert's labours than are to be found in his celebrated work "De Magnete," published in the year I60s. Such as it is, this work may, however, be justly regarded as the earliest English scientific clasvic, and its author must be recognized as the first truly philosophical investigator in the now all-important subjects of electricity and magnetism. The Club has been organized for the object of bringing out an English edition of "De Magnete" as nearly as possible in the style of the original folio edition, and to arrange for a befitting celebration of the tercentenary of this work in the year 1900 . To quote the circular:- "The publication of "De Magnete" not only marked an epoch in the science of magnetism, but constituted the absolute starting-point of the science of electricity. It has been hitherto a reproach to British electricians that they too little recognized the merits of the founder of the science." The preliminary list of members already includes the names of Sir William Thomson, Lord Rayleigh, Prof. Tyndall, Sir John Lubbock, Prof. Ruicker, Prof, Lodge, Mr. Preece, Prof. Reinold, Prof. Perry, Prof. G.-Forbes, Prof. D. E. Hughes, Sir F. A. Abel, Sir F. Bramwell, Sir Douglas Galton, Sir H. Mance, Colonel Festing, Captain Abney, Prof. Carey Foster, Prof. W. G. Adams, Prof. J. C. Adams, Prof. Roberts-Austen, Prof. Thorpe, Prof. G. H. Darwin, Prof. Liveing, Prof. Dewar, Prof, W. N. Shaw, Prof. Poynting, Prof. Ray Lankester, Mr. Crookes, Mr. J. Hopkinson, Mr. Glazebrook, Mr. G. J. Symons, Dr. J. H. Gladstone, Dr. B. W. Richardson, Prof. Victor Horsley, Mr. Latimer Clark, \&c.

DR. QUESNEVILIE, the French chemist, died on November $\mathrm{I}_{4}$, at the age of eighty. $\mathrm{He}$ took his degree of doctor o 